\title{
Study on the Behavioral Health Risk Factors of Sewing Industry Workers in Bulgaria
}

\author{
Assoc. Prof. Jeni Staykova, \\ $\mathrm{MD}, \mathrm{PhD}$, Medical University - Sofia, Bulgaria, \\ Maria Titopoulou \\ PhD, LOT-CONSULT EOOD, Sofia, Bulgaria,
}

\begin{abstract}
The chronic non-communicable diseases in the last twenty years have been a major priority of the World Health Organisation (WHO) due to their epidemic character. These diseases lead to morbidity, mortality and invalidization which have a great health, social and economic effect. The main reason for triggering the chronic non-communicable diseases are the behavioral health risk factors of life such as nutrition, physical activity, smoking and the use of alcohol. The risk factors are characteristics at the biological, psychological, family, community, or cultural level that precede and are associated with a higher likelihood of negative outcomes. Since these factors are manageable, it is essential to carry out targeted health policy among the working people aiming at their optimization which correlates to the improved health status of the population as a whole. A suitable group for study of the behavioral risk factors are the organized groups of workers within enterprises.

Our study is conducted among 503 working people in an enterprise of the sewing industry in Bulgaria in 2015.
\end{abstract}

Keywords: behavioral health risk factors, health status, nutrition, locomotor activity, concentated alcoholoc drinks

\section{Introduction}

The aim of this study is to analyze the main behavioral risk factors among workers in an enterprise from the sewing industry in Bulgaria and to identify measures for their oprimization.

\section{Objectives of the study:}

1. To select a representative sample of workers carrying out various activities in the clothing business.

2. To conduct a survey among workers including questions identifying their lifestyle.

3. To analyze the results and to identify appropriate measures aiming at optimization of the behavioral factors.

Materials and methods: A survey for the behavioral risk factors of life is conducted among 503 workers in an enterprise from the sewing industry in Bulgaria. Of these 71 men and 432 women, aged 20 to 65 years, divided in six age groups and evaluated according to their sex and level of education.

The questionnaire is adapted and structured in order to obtain information on the main behavioral risk factors (nutrition, physical exercising, smoking and alcohol use). The questionnaire includes two parts: passport part with information about sex, date of birth, age and education of respondents and part two: Risk factors for the health, including information on behavioral risk factors of health (nutrition, physical activity, smoking and alcohol use).

Data is processed statistically by SPSS/PSPP analysis.

\section{Results and discussion:}

\section{General characteristics of the respondents}

From the included in the survey 503 persons, 71 are men and 432 - women, aged 20-65, arranged into six age groups as indicated below (Table 1). 
Table 1

\begin{tabular}{|c|c|c|c|c|c|c|c|c|c|c|c|c|c|c|}
\hline & \multicolumn{7}{|l|}{ Men } & \multicolumn{7}{|c|}{ Women } \\
\hline & $<25$ & $\begin{array}{l}25- \\
34\end{array}$ & $\begin{array}{l}35- \\
44\end{array}$ & $\begin{array}{l}45- \\
54\end{array}$ & $\begin{array}{l}55- \\
64\end{array}$ & $>65$ & total & $<25$ & $\begin{array}{l}25- \\
34\end{array}$ & $\begin{array}{l}35- \\
44\end{array}$ & $\begin{array}{l}45- \\
54\end{array}$ & $\begin{array}{l}55- \\
64\end{array}$ & $>65$ & total \\
\hline number & 3 & 13 & 26 & 13 & 15 & 1 & 71 & 1 & 31 & 104 & 158 & 136 & 2 & 432 \\
\hline$\%$ & 4,2 & 18,3 & 36,6 & 18,3 & 21,1 & 1,4 & 100,0 & 0,2 & 7,2 & 24,1 & 36,6 & 31,5 & 0,5 & 100,0 \\
\hline
\end{tabular}

The respondents with secondary education have the largest share $-85.9 \%$ men and $87.0 \%$ women. With higher education are $7.0 \%$ of men and $5.0 \%$ of women. Every $17^{\text {th }}$ man and $13^{\text {th }}$ woman attended school until the $8^{\text {th }}$ grade. With elementary educated workers are respectively $1.4 \%$ and $0.8 \%$ of men and women, without education $-0.2 \%$ of women (Table 2 ).

Table 2

\begin{tabular}{|l|l|l|l|l|l|l|}
\hline \multirow{2}{*}{ Education degree } & \multicolumn{2}{|l|}{ Men } & Women & \multicolumn{2}{l|}{ Total } \\
\cline { 2 - 8 } & number & $\%$ & number & $\%$ & number & $\%$ \\
\hline none & 0 & 0,0 & 1 & 0,2 & 1 & 0,2 \\
\hline elementary & 1 & 1,4 & 3 & 0,7 & 4 & 0,8 \\
\hline primary & 4 & 5,6 & 32 & 7,4 & 36 & 7,2 \\
\hline secondary & 61 & 85,9 & 376 & 87,0 & 437 & 86,9 \\
\hline higher & 5 & 7,0 & 20 & 4,6 & 25 & 5,0 \\
\hline
\end{tabular}

\section{Behavioral Health Risk Factors}

\section{Nutrition}

Rational nutrition is one of the main factors for good health. The survey results show that $71.8 \%$ of men and $59.7 \%$ of women have regularly breakfast in the morning. Accordingly, $28.2 \%$ of men and $40.3 \%$ of women do not have breakfast. It is known that breakfast is very important for health; the obesrvation of this statement by the surveyed is relatively satisfiyng (Table 3).

\section{Table 3}

\begin{tabular}{|l|l|l|l|l|l|l|}
\hline \multirow{2}{*}{ Do you have breakfast? } & \multicolumn{2}{|l|}{ Men } & Women & \multicolumn{2}{l|}{ Total } \\
\cline { 2 - 7 } & number & $\%$ & number & $\%$ & number & $\%$ \\
\hline yes & 51 & 71,8 & 258 & 59,7 & 309 & 61,4 \\
\hline no & 20 & 28,2 & 174 & 40,3 & 194 & 38,6 \\
\hline
\end{tabular}

$66.2 \%$ of men and $59.0 \%$ of women eat three times a day, and twice a day - respectively $19.7 \%$ and $27.3 \%$ of them. Four times $-9.9 \%$ of men and $8.3 \%$ of women. The percentage of persons eating single time a day is about $2.4 \%$. Those receiving food five times or more also have a small share $-2.8 \%$ (Table 4 ).

Table 4

\begin{tabular}{|l|l|l|l|l|l|l|}
\hline \multirow{2}{*}{ How many times do you eat per day? } & \multicolumn{2}{l}{ Men } & Women & \multicolumn{2}{l|}{ Total } \\
\cline { 2 - 8 } & number & $\%$ & number & $\%$ & number & $\%$ \\
\hline 1 & 1 & 1,4 & 11 & 2,5 & 12 & 2,4 \\
\hline 2 & 14 & 19,7 & 118 & 27,3 & 132 & 26,2 \\
\hline 3 & 47 & 66,2 & 255 & 59,0 & 302 & 60,0 \\
\hline 4 & 7 & 9,9 & 36 & 8,3 & 43 & 8,5 \\
\hline more & 2 & 2,8 & 12 & 2,8 & 14 & 2,8 \\
\hline
\end{tabular}


The fat used in the preparation of food is the sunflower oil in $94.6 \%$ of cases. Olive oil, grease or similar fats are used rarely - in about $6.0 \%$ of cases (Table 5 ).

Table 5

\begin{tabular}{|l|l|l|l|l|l|l|}
\hline \multirow{2}{*}{ What kind of fats do you use for cooking? } & \multicolumn{2}{|l|}{ Men } & Women & \multicolumn{2}{l|}{ Total } \\
\cline { 2 - 8 } & number & $\%$ & number & $\%$ & number & $\%$ \\
\hline sunflower oil & 65 & 91,5 & 411 & 95,1 & 476 & 94,6 \\
\hline margarine & 1 & 1,4 & 2 & 0,5 & 3 & 0,6 \\
\hline olive oil & 4 & 5,6 & 10 & 2,3 & 14 & 2,8 \\
\hline grease & 1 & 1,4 & 5 & 1,2 & 6 & 1,2 \\
\hline I don't use fats & 0 & 0,0 & 4 & 0,9 & 4 & 0,8 \\
\hline
\end{tabular}

Bread is another typical product of nutrition for the Bulgarian workers. $79.3 \%$ of the respondents consume white bread, more expressed in men $-87.3 \%$ against $78.0 \%$ in women. $92.0 \%$ of men and women do not consume rye bread. The consumption of brown bread is slightly higher (8.5\%). Other types of bread are consumed by about $0.8 \%$ of men and women, and $3.4 \%$ of them do not eat bread (Table 6$)$.

Table 6

\begin{tabular}{|l|l|l|l|l|l|l|}
\hline \multirow{2}{*}{ What kind of bread do you consume? } & \multicolumn{2}{l}{ Men } & Women & \multicolumn{2}{l|}{ Total } \\
\cline { 2 - 8 } & number & $\%$ & number & $\%$ & number & $\%$ \\
\hline rye/whole grain bread & 5 & 7,0 & 35 & 8,1 & 40 & 8,0 \\
\hline brown bread & 1 & 1,4 & 42 & 9,7 & 43 & 8,5 \\
\hline white bread & 62 & 87,3 & 337 & 78,0 & 399 & 79,3 \\
\hline other & 0 & 0,0 & 4 & 0,9 & 4 & 0,8 \\
\hline I don't eat bread & 3 & 4,2 & 14 & 3,2 & 17 & 3,4 \\
\hline
\end{tabular}

The consumption of 2 cups of coffee has the highest proportion among men and women - $46.9 \% ; 25.0 \%$ of the respondents indicated that they drink 1 cup of coffee; $16.9 \%$ - 3 cups, and $3.8 \%$ - more. $19.7 \%$ of men and $5.3 \%$ of women do not drink coffee (Table 7).

\section{Table 7}

\begin{tabular}{|l|l|l|l|l|l|l|}
\hline \multirow{2}{*}{$\begin{array}{l}\text { How many cups of coffee do you drink per } \\
\text { day? }\end{array}$} & \multicolumn{2}{|l|}{ Men } & Women & \multicolumn{2}{l|}{ Total } \\
\cline { 2 - 7 } & number & $\%$ & number & $\%$ & number & $\%$ \\
\hline 1 & 12 & 16,9 & 114 & 26,4 & 126 & 25,0 \\
\hline 2 & 29 & 40,8 & 207 & 47,9 & 236 & 46,9 \\
\hline 3 & 10 & 14,1 & 75 & 17,4 & 85 & 16,9 \\
\hline more & 6 & 8,5 & 13 & 3,0 & 19 & 3,8 \\
\hline I don't drink coffee & 14 & 19,7 & 23 & 5,3 & 37 & 7,4 \\
\hline
\end{tabular}

The consumption of salt among the population is high, both before and after tasting the food. The data shows that $67.6 \%$ of men and $66.0 \%$ of women add extra salt to the food after tasting it. $9.9 \%$ of men and $11.1 \%$ of women add extra salt to the food before tasting it. Only $1.6 \%$ of the respondents consume unsalted food (Table 8).

Table 8

\begin{tabular}{|l|l|l|l|l|l|l|}
\hline \multirow{3}{*}{ Do you add extra salt to your food? } & \multicolumn{2}{|l|}{ Men } & Women & \multicolumn{2}{l|}{ Total } \\
\cline { 2 - 7 } & number & $\%$ & number & $\%$ & number & $\%$ \\
\hline
\end{tabular}




\begin{tabular}{|l|l|l|l|l|l|l|} 
never & 15 & 21,1 & 92 & 21,3 & 107 & 21,3 \\
\hline sometimes & 48 & 67,6 & 285 & 66,0 & 333 & 66,2 \\
\hline always & 7 & 9,9 & 48 & 11,1 & 55 & 10,9 \\
\hline I eat unsalted food & 1 & 1,4 & 7 & 1,6 & 8 & 1,6 \\
\hline
\end{tabular}

$21.9 \%$ of the surveyed men and women consume carbonated drinks very often; rarely - $64.4 \%$; and $13.7 \%$ of them do not consume carbonated drinks (Table 9).

\section{Table 9}

\begin{tabular}{|l|l|l|l|l|l|l|}
\hline \multirow{2}{*}{$\begin{array}{l}\text { Do you consume carbonated drinks in your } \\
\text { family? }\end{array}$} & \multicolumn{2}{|l|}{ Men } & Women & \multicolumn{2}{l|}{ Total } \\
\cline { 2 - 8 } & number & $\%$ & number & $\%$ & number & $\%$ \\
\hline very often & 18 & 25,4 & 92 & 21,3 & 110 & 21,9 \\
\hline rarely & 47 & 66,2 & 277 & 64,1 & 324 & 64,4 \\
\hline we don't & 6 & 8,5 & 63 & 14,6 & 69 & 13,7 \\
\hline
\end{tabular}

$4.2 \%$ of men and $5.3 \%$ of women follow a diet plan. $15.5 \%$ of men and $28.2 \%$ of women indicated that they rarely follow diets. The data shows that about $68.4 \%$ of the surveyed men and women do not follow dietary regimes (Table 10 ).

\section{Table 10}

\begin{tabular}{|l|l|l|l|l|l|l|}
\hline \multirow{2}{*}{ Do you follow any dietary regimen? } & \multicolumn{2}{l}{ Men } & Women & \multicolumn{2}{l|}{ Total } \\
\cline { 2 - 8 } & number & $\%$ & number & $\%$ & number & $\%$ \\
\hline very often & 3 & 4,2 & 23 & 5,3 & 26 & 5,2 \\
\hline rarely & 11 & 15,5 & 122 & 28,2 & 133 & 26,4 \\
\hline I don't & 57 & 80,3 & 287 & 66,4 & 344 & 68,4 \\
\hline
\end{tabular}

$52.1 \%$ of the respondents consider that they are with a normal weight; 32.6 percent - overweighted, and $4.2 \%$ underweighted. $5.6 \%$ of men and $12.0 \%$ of women are unable to make an estimate (Table 11).

\section{Table 11}

\begin{tabular}{|l|l|l|l|l|l|l|}
\hline & \multicolumn{3}{|l}{ Men } & Women & \multicolumn{2}{l|}{ Total } \\
\cline { 2 - 8 } What is your weight in your opinion? & number & $\%$ & number & $\%$ & number & $\%$ \\
\hline Normal & 43 & 60,6 & 219 & 50,7 & 262 & 52,1 \\
\hline Underweight & 5 & 7,0 & 16 & 3,7 & 21 & 4,2 \\
\hline Overweighted & 19 & 26,8 & 145 & 33,6 & 164 & 32,6 \\
\hline I do not know & 4 & 5,6 & 52 & 12,0 & 56 & 11,1 \\
\hline
\end{tabular}

The healthy nutrition' principles are unknown to $3.6 \%$ for men and women. $57.7 \%$ are interested in them, and $38 \%$ did not show an interest in them (Table 12).

Table 12

\begin{tabular}{|l|l|l|l|l|l|l|}
\hline \multirow{2}{*}{$\begin{array}{l}\text { Are you interested in the principles of healthy } \\
\text { nutrition? }\end{array}$} & \multicolumn{2}{|l|}{ Men } & Women & \multicolumn{2}{l|}{ Total } \\
\cline { 2 - 8 } & number & $\%$ & number & $\%$ & number & $\%$ \\
\hline yes & 38 & 53,5 & 252 & 58,3 & 290 & 57,7 \\
\hline no & 30 & 42,3 & 165 & 38,2 & 195 & 38,8 \\
\hline
\end{tabular}




\section{Conclusions:}

- $\quad$ the frequency of eating is triple for $66.2 \%$ of men and $59.0 \%$ women;

- $\quad$ morning breakfast was not accepted by nearly every third man and woman;

- $\quad$ the consumption of white bread dominates;

- $\quad$ high proportion of persons adding salt to food after tasting is observed $-66.2 \%$ of men and women, and every ninth - before tasting the food;

- a change in eating habits have undertaken $31.6 \%$ of men and women, as $5.2 \%$ - very often, and $26.4 \%$ - rarely.

\section{Motor activity}

Physical exersising is an important factor for the health and self-esteem of the persons. The low physical activity is a serious risk factor for health in the sewing industry. Doing exercise during leisure time is an investment in health.

The results showed that the share of those who do so is low - only $10.7 \% ; 25.0 \%$ of men and $1.4 \%$ of women are doing exercise very rarely in the morning or during free time and $64.2 \%$ - not at all (Table 13).

Table 13

\begin{tabular}{|l|l|l|l|l|l|l|}
\hline \multirow{2}{*}{$\begin{array}{l}\text { In the morning or during your free time do you } \\
\text { physical exercises? }\end{array}$} & \multicolumn{2}{|l|}{ Men } & \multicolumn{2}{l|}{ Women } & \multicolumn{2}{l|}{ Total } \\
\cline { 2 - 7 } & number & $\%$ & number & $\%$ & number & $\%$ \\
\hline Yes & 14 & 19,7 & 40 & 9,3 & 54 & 10,7 \\
\hline No & 38 & 53,5 & 285 & 66,0 & 323 & 64,2 \\
\hline Very rarely & 19 & 26,8 & 107 & 24,8 & 126 & 25,0 \\
\hline
\end{tabular}

The visits in the gym also showed extremely unsatisfactory results. Only $2,6 \%$ of the respondents visit the gyms, and $4.4 \%$ - do it very rarely (Table 14).

Table 14

\begin{tabular}{|l|l|l|l|l|l|l|}
\hline \multirow{2}{*}{ Do you visit a gym/fitness center? } & \multicolumn{2}{l}{ Men } & \multicolumn{2}{l|}{ Women } & \multicolumn{2}{l|}{ Total } \\
\cline { 2 - 8 } & number & $\%$ & number & $\%$ & number & $\%$ \\
\hline Yes & 4 & 5,6 & 9 & 2,1 & 13 & 2,6 \\
\hline No & 59 & 83,1 & 409 & 94,7 & 468 & 93,0 \\
\hline Very rarely & 8 & 11,3 & 14 & 3,2 & 22 & 4,4 \\
\hline
\end{tabular}

The survey results showed that for $15.5 \%$ of the men and $13.7 \%$ of women the weekly physical activity is light; in $69.0 \%$ of men and $75.2 \%$ of women it is moderate, while in $15.5 \%$ of men and $11.1 \%$ of women - vigorous (Table 15).

\section{Table 15}

\begin{tabular}{|l|l|l|l|l|l|l|}
\hline \multirow{2}{*}{ What is your weekly physical activity? } & \multicolumn{4}{|l|}{ Men } & Women & \multicolumn{2}{l|}{ Total } \\
\cline { 2 - 8 } & number & $\%$ & number & $\%$ & number & $\%$ \\
\hline Light & 11 & 15,5 & 59 & 13,7 & 70 & 13,9 \\
\hline Moderate & 49 & 69,0 & 325 & 75,2 & 374 & 74,4 \\
\hline Vigorous & 11 & 15,5 & 48 & 11,1 & 59 & 11,7 \\
\hline
\end{tabular}


Walking is the most accessible physical activity for health according to the respondents in the survey. The survey results show that $79.9 \%$ of men and women love walking, as most do it every day for at least 15-20 minutes (Tables 16 and 17).

Table 16

\begin{tabular}{|l|l|l|l|l|l|l|}
\hline \multirow{2}{*}{ Do you like to walk? } & \multicolumn{3}{|l|}{ Men } & \multicolumn{2}{l|}{ Women } & \multicolumn{2}{l|}{ Total } \\
\cline { 2 - 8 } & number & $\%$ & number & $\%$ & number & $\%$ \\
\hline Yes & 60 & 84,5 & 342 & 79,2 & 402 & 79,9 \\
\hline Non & 11 & 15,5 & 90 & 20,8 & 101 & 20,1 \\
\hline
\end{tabular}

\section{Table 17}

\begin{tabular}{|l|l|l|l|l|l|l|}
\hline \multirow{2}{*}{ If yes, how often do this in the week? } & Men & Women & \multicolumn{2}{l|}{ Total } \\
\cline { 2 - 7 } & number & $\%$ & number & $\%$ & number & $\%$ \\
\hline Every day 15-20 min. & 28 & 46,7 & 168 & 49,1 & 196 & 48,8 \\
\hline two or three times at least per 15 min. & 6 & 10,0 & 37 & 10,8 & 43 & 10,7 \\
\hline morning and evening for at least 30 minutes. & 14 & 23,3 & 98 & 28,7 & 112 & 27,9 \\
\hline more than 60 min. daily & 12 & 20,0 & 39 & 11,4 & 51 & 12,7 \\
\hline
\end{tabular}

In the sitting position during 1-2 hours the day are staying $21,7 \%$ of men and women, for $3-4$ hours a day $-10,5 \%$, and more than six hours a day $-67,8 \%$ (Table 18 ).

Table 18

\begin{tabular}{|l|l|l|l|l|l|l|}
\hline \multirow{2}{*}{$\begin{array}{l}\text { How many hours per day do you spend in } \\
\text { sitting position? }\end{array}$} & \multicolumn{3}{|l|}{ Men } & Women & \multicolumn{2}{l|}{ Total } \\
\cline { 2 - 7 } & number & $\%$ & number & $\%$ & number & $\%$ \\
\hline at least 1-2 hours & 41 & 57,7 & 68 & 15,7 & 109 & 21,7 \\
\hline at least 3-4 hours & 14 & 19,7 & 39 & 9,0 & 53 & 10,5 \\
\hline more than 6 hours a day & 16 & 22,5 & 325 & 75,2 & 341 & 67,8 \\
\hline
\end{tabular}

Conclusions: The level of the motor activity of the respondents is low, which implies a serious risk for the health.

\section{Knowledge, skills and health behavior}

The awareness of the surveyed persons about the individual elements of the healthy life style varies.

With the harm of smoking on health are familiar $90,3 \%$ of men and women. This information is characteristic for both genders. However, 1,6\% are not familiar that tobacco is harmful (Table 19).

\section{Table 19}

\begin{tabular}{|l|l|l|l|l|l|l|}
\hline \multirow{2}{*}{$\begin{array}{l}\text { Do you believe that smoking is harmful to } \\
\text { health? }\end{array}$} & \multicolumn{2}{|l|}{ Men } & \multicolumn{2}{l|}{ Women } & \multicolumn{2}{l|}{ Total } \\
\cline { 2 - 8 } & number & $\%$ & number & $\%$ & number & $\%$ \\
\hline Yes & 67 & 94,4 & 387 & 89,6 & 454 & 90,3 \\
\hline No & 1 & 1,4 & 6 & 1,4 & 7 & 1,4 \\
\hline May be & 1 & 1,4 & 33 & 7,6 & 34 & 6,8 \\
\hline
\end{tabular}


\begin{tabular}{|l|l|l|l|l|l|l|} 
I do not know & 2 & 2,8 & 6 & 1,4 & 8 & 1,6 \\
\hline
\end{tabular} $86,1 \%$ of men and women believe that alcohol abuse leads to negative health effects. In that are not confident $8,0 \%$ and $4,8 \%$ do not know. Alcohol is a stimulant for $1,2 \%$ the respondents (Table 20 ).

Table 20

\begin{tabular}{|l|l|l|l|l|l|l|}
\hline \multirow{2}{*}{$\begin{array}{l}\text { Do you consider that the alcohol is harmful to } \\
\text { health? }\end{array}$} & \multicolumn{4}{|l|}{ Men } & Women & \multicolumn{2}{l|}{ Total } \\
\cline { 2 - 8 } & number & $\%$ & number & $\%$ & number & $\%$ \\
\hline yes, when abused & 62 & 87,3 & 371 & 85,9 & 433 & 86,1 \\
\hline No, it is stimulating & 1 & 1,4 & 5 & 1,2 & 6 & 1,2 \\
\hline May be & 6 & 8,5 & 34 & 7,9 & 40 & 8,0 \\
\hline I do not know & 2 & 2,8 & 22 & 5,1 & 24 & 4,8 \\
\hline
\end{tabular}

The majority of the surveyed workers $(90,1 \%)$ believe that the physical activity is of great importance for their health (Table 21).

\section{Table 21}

\begin{tabular}{|l|l|l|l|l|l|l|}
\hline \multirow{2}{*}{$\begin{array}{l}\text { Do you think that the physical activity is of } \\
\text { great importance for the health? }\end{array}$} & \multicolumn{2}{l}{ Men } & \multicolumn{2}{l|}{ Women } & \multicolumn{2}{l|}{ Total } \\
\cline { 2 - 8 } & number & $\%$ & number & $\%$ & number & $\%$ \\
\hline Yes & 66 & 93,0 & 387 & 89,6 & 453 & 90,1 \\
\hline No & 0 & 0,0 & 4 & 0,9 & 4 & 0,8 \\
\hline Maybe & 4 & 5,6 & 29 & 6,7 & 33 & 6,6 \\
\hline I do not know & 1 & 1,4 & 12 & 2,8 & 13 & 2,6 \\
\hline
\end{tabular}

$95,4 \%$ of the surveyed are convinced about the importance of the diet on health. $3,8 \%$ of the surveyed have no knowledge on the matter, and only $0,8 \%$ reported that it was not important (Table 22).

Table 22

\begin{tabular}{|l|l|l|l|l|l|l|}
\hline \multirow{2}{*}{$\begin{array}{l}\text { Do you consider that the diet is important for } \\
\text { the good health? }\end{array}$} & \multicolumn{4}{|l|}{ Men } & Women & \multicolumn{2}{l|}{ Total } \\
\cline { 2 - 7 } & number & $\%$ & number & $\%$ & number & $\%$ \\
\hline Yes, it is important & 66 & 93,0 & 414 & 95,8 & 480 & 95,4 \\
\hline No, it is not important & 2 & 2,8 & 2 & 0,5 & 4 & 0,8 \\
\hline I do not know & 3 & 4,2 & 16 & 3,7 & 19 & 3,8 \\
\hline
\end{tabular}

Most of surveyed workers receive information about healthy lifestyle from their GP - $39.2 \%$. The media are the main source of information for $36.4 \% .18 .7 \%$ rely on the experience of friends and $5.8 \%$ on the campaigns of the Regional Health Inspectorates (RHI) - Table 23.

\section{Table 23}

\begin{tabular}{|l|l|l|l|l|l|l|}
\hline \multirow{2}{*}{$\begin{array}{l}\text { From where you receive information about the } \\
\text { healthy lifestyle? }\end{array}$} & \multicolumn{4}{|l|}{ Men } & Women & \multicolumn{2}{l|}{ Total } \\
\cline { 2 - 8 } & number & $\%$ & number & $\%$ & number & $\%$ \\
\hline $\begin{array}{l}\text { From the campaigns of the Regional Health } \\
\text { Inspectorates }\end{array}$ & 6 & 8,5 & 23 & 5,3 & 29 & 5,8 \\
\hline From the media & 28 & 39,4 & 155 & 35,9 & 183 & 36,4 \\
\hline Form my GP & 22 & 31,0 & 175 & 40,5 & 197 & 39,2 \\
\hline From friends & 15 & 21,1 & 79 & 18,3 & 94 & 18,7 \\
\hline
\end{tabular}

\section{Smoking}


The results of the survey conducted showed that $49.3 \%$ of men and $56.3 \%$ of women live in families of smokers (Table 24). It can be said that every $11^{\text {th }}$ man smoker and every $18^{\text {th }}$ woman passes over five hours per day in a tobacco smoke environment. Besides them, $14.4 \%$ of men and $11.1 \%$ of women are in a smoke environment for 1 to 4 hours. For $78.6 \%$ of men and $84.6 \%$ of women the environment at home and in the workplace is almost tobacco smoke free (Table 25).

Table 24

\begin{tabular}{|l|l|l|l|l|l|l|}
\hline \multirow{2}{*}{$\begin{array}{l}\text { Do you have any smokers } \\
\text { in the family? }\end{array}$} & \multicolumn{2}{|l|}{ Men } & Women & \multicolumn{2}{l|}{ Total } \\
\cline { 2 - 8 } & number & $\%$ & number & $\%$ & number & $\%$ \\
\hline yes & 35 & 49,3 & 243 & 56,3 & 278 & 55,3 \\
\hline no & 36 & 50,7 & 189 & 43,8 & 225 & 44,7 \\
\hline
\end{tabular}

Table 25

\begin{tabular}{|l|l|l|l|l|l|l|}
\hline \multirow{2}{*}{$\begin{array}{l}\text { If you are not a smoker, how many hours per day } \\
\text { you spend in a place where someone else } \\
\text { smokes? }\end{array}$} & \multicolumn{2}{|l|}{ Men } & Women & \multicolumn{2}{l|}{ Total } \\
\cline { 2 - 8 } & number & $\%$ & number & $\%$ & number & $\%$ \\
\hline 0 & 33 & 78,6 & 247 & 84,6 & 280 & 83,8 \\
\hline 1 & 2 & 4,8 & 16 & 5,5 & 18 & 5,4 \\
\hline 2 & 2 & 4,8 & 6 & 2,1 & 8 & 2,4 \\
\hline 3 & 2 & 4,8 & 6 & 2,1 & 8 & 2,4 \\
\hline 4 & 0 & 0,0 & 4 & 1,4 & 4 & 1,2 \\
\hline 5 and more hours & 3 & 7,1 & 13 & 4,5 & 16 & 4,8 \\
\hline
\end{tabular}

The data shows that $40.8 \%$ of men and $32.4 \%$ of women are smokers. The remaining $59.2 \%$ of men and $67.6 \%$ of women are non-smokers (Table 26).

Table 26

\begin{tabular}{|l|l|l|l|l|l|l|}
\hline \multirow{2}{*}{ Are you a smoker? } & \multicolumn{2}{|l|}{ Men } & Women & \multicolumn{2}{l|}{ Total } \\
\cline { 2 - 7 } & number & $\%$ & number & $\%$ & number & $\%$ \\
\hline yes & 29 & 40,8 & 140 & 32,4 & 169 & 33,6 \\
\hline no & 42 & 59,2 & 292 & 67,6 & 334 & 66,4 \\
\hline
\end{tabular}

Every $5^{\text {th }}$ surveyed man smoker and $7^{\text {th }}$ woman has started smoking at the age under 18 . The largest share is of those who began smoking between 18 and 25 years old for men and women (respectively $75.9 \%$ and $75.0 \%$ ). An interesting fact is that $11.4 \%$ of women started smoking after the age of 25 , while men share in this case is only $3.4 \%$ (Table 27 ).

Table 27

\begin{tabular}{|l|l|l|l|l|l|l|}
\hline \multirow{2}{*}{ What age did you start smoking? } & \multicolumn{2}{|l|}{ Men } & Women & \multicolumn{3}{l|}{ Total } \\
\cline { 2 - 7 } & number & $\%$ & number & $\%$ & number & $\%$ \\
\hline under 18 years old & 6 & 20,7 & 19 & 13,6 & 25 & 14,8 \\
\hline 18-25 years old & 22 & 75,9 & 105 & 75,0 & 127 & 75,1 \\
\hline above 25 years old & 1 & 3,4 & 16 & 11,4 & 17 & 10,1 \\
\hline
\end{tabular}

The intensity of smoking among men and women has significant differences. Women are mostly moderate smokers (1-10 cigarettes daily) $-80.7 \%$ of them, while for men the proportion is $51.7 \%$. As regards to men, every second is an intense smoker (11-20 cigarettes per day), while for women it can be said for every fifth is a smoker. A positive fact is that in both sexes there are no heavy smokers ( $>=21$ cigarettes per day) - Table 28. 


\section{Table 28}

\begin{tabular}{|l|l|l|l|l|l|l|}
\hline \multirow{2}{*}{$\begin{array}{l}\text { If you are not a smoker, how many } \\
\text { hours do you spend at a place, where someone else smokes? }\end{array}$} & \multicolumn{2}{l|}{ Men } & number & $\%$ & nomen & \multicolumn{2}{l|}{ Total } \\
\hline $1-10$ (moderate) & 15 & 51,7 & 113 & 80,7 & 128 & 75,7 \\
\hline $11-20$ (intense) & 14 & 48,3 & 27 & 19,3 & 41 & 24,3 \\
\hline$>=21$ (heavy) & 0 & 0,0 & 0 & 0,0 & 0 & 0,0 \\
\hline
\end{tabular}

Many smokers attempt to quit smoking. This does not always end up with success. The results of the survey show that $69.0 \%$ of men and $60.0 \%$ wish to quit. Every fourth man smoker and every third woman does not wish to quit smoking (Table 29).

\section{Table 29}

\begin{tabular}{|l|l|l|l|l|l|l|}
\hline \multirow{2}{*}{ Do you wish to quit smoking? } & \multicolumn{2}{|l|}{ Men } & \multicolumn{2}{l|}{ Women } & \multicolumn{2}{l|}{ Total } \\
\cline { 2 - 7 } & number & $\%$ & number & $\%$ & number & $\%$ \\
\hline yes & 20 & 69,0 & 84 & 60,0 & 104 & 61,5 \\
\hline no & 9 & 31,0 & 56 & 40,0 & 65 & 38,5 \\
\hline
\end{tabular}

The data shows that more than half of the smokers of both sexes have tried to quit smoking $-59.2 \%$. Almost every third man smoker has never made an attempt to quit smoking and as regards women - $41.4 \%$ of them (Table 30 ).

Table 30

\begin{tabular}{|l|l|l|l|l|l|l|}
\hline \multirow{2}{*}{$\begin{array}{l}\text { Have you ever made an attempt } \\
\text { to quit smoking? }\end{array}$} & \multicolumn{2}{|l|}{ Men } & Women & \multicolumn{2}{l|}{ Total } \\
\cline { 2 - 7 } & number & $\%$ & number & $\%$ & number & $\%$ \\
\hline yes & 18 & 62,1 & 82 & 58,6 & 100 & 59,2 \\
\hline no & 11 & 37,9 & 58 & 41,4 & 69 & 40,8 \\
\hline
\end{tabular}

Alcohol Consumption

Alcohol is one of the risk factors for health when abusing with. Survey data showed that $22.5 \%$ of men and $59.5 \%$ of women do not consume alcohol. Very rarely do so respectively $35.2 \%$ and $36.6 \%$ of them. Regular consumers of alcohol are $42.3 \%$ of the men and $3.9 \%$ of the women (Table 31 ).

Table 31

\begin{tabular}{|l|l|l|l|l|l|l|}
\hline \multirow{2}{*}{ Are you taking alcohol? } & \multicolumn{2}{l}{ Men } & Women & \multicolumn{2}{l|}{ Total } \\
\cline { 2 - 8 } & number & $\%$ & number & $\%$ & number & $\%$ \\
\hline Yes & 30 & 42,3 & 17 & 3,9 & 47 & 9,3 \\
\hline No & 16 & 22,5 & 232 & 53,7 & 248 & 49,3 \\
\hline Very rarely & 25 & 35,2 & 158 & 36,6 & 183 & 36,4 \\
\hline I never consume & 0 & 0,0 & 25 & 5,8 & 25 & 5,0 \\
\hline
\end{tabular}

The data showed that $41.8 \%$ of the men and $78.3 \%$ of the women consume alcohol once a week. $40.0 \%$ of the men and $17.1 \%$ of the women consume alcohol $2-3$ times per week and $18.2 \%$ of the men and $4.6 \%$ of the women - every day (Table 32).

\section{Table 32}

\begin{tabular}{|l|l|l|l|}
\hline If you use, how many times per week? & Men & Women & Total \\
\hline
\end{tabular}




\begin{tabular}{|l|l|l|l|l|l|l|}
\cline { 1 - 6 } & number & $\%$ & number & $\%$ & number & $\%$ \\
\hline Once & 23 & 41,8 & 137 & 78,3 & 160 & 69,6 \\
\hline Two - three times & 22 & 40,0 & 30 & 17,1 & 52 & 22,6 \\
\hline Every day & 10 & 18,2 & 8 & 4,6 & 18 & 7,8 \\
\hline
\end{tabular}

There are differences in the consumption of different the types of alcoholic beverages, shown on Table 33 below:

Table 33

\begin{tabular}{|l|l|l|l|l|l|l|}
\hline \multirow{2}{*}{ If you drink alcohol, what kind you prefer? } & \multicolumn{3}{l}{ Men } & Women & \multicolumn{2}{l|}{ Total } \\
\cline { 2 - 8 } & number & $\%$ & number & $\%$ & number & $\%$ \\
\hline Concentrate & 25 & 45,5 & 55 & 31,4 & 80 & 34,8 \\
\hline Vine & 9 & 16,4 & 82 & 46,9 & 91 & 39,6 \\
\hline Beer & 21 & 38,2 & 38 & 21,7 & 59 & 25,7 \\
\hline
\end{tabular}

Concentrates are preferred drink almost every second man and third women. Within men, those consuming the highest share of 1 cup at a time are $64.0 \%$. The relative share of the consumers of 2 (two) cups of concentrate is $28.0 \%$, while the next group ( 3 cups) are $8.0 \%$.

The case within women is different. In this group the consumption is lower than that of males, most often 1 cup portion at $85.5 \%$ of them. Every seventh woman consumed 2 cups. There are no cases with consumption of 3 or more cups at once (Table 34).

\section{Table 34}

\begin{tabular}{|l|l|l|l|l|l|l|}
\hline \multirow{2}{*}{$\begin{array}{l}\text { If you use it what quantity you drink at once } \\
\text { (concentrate) }\end{array}$} & \multicolumn{2}{|l|}{ Men } & Women & \multicolumn{2}{l|}{ Total } \\
\cline { 2 - 8 } & number & $\%$ & number & $\%$ & number & $\%$ \\
\hline 1 cup & 16 & 64,0 & 47 & 85,5 & 63 & 78,8 \\
\hline 2 cups & 7 & 28,0 & 8 & 14,5 & 15 & 18,8 \\
\hline 3 cups & 2 & 8,0 & 0 & 0,0 & 2 & 2,5 \\
\hline
\end{tabular}

The vine is a drink for $16,4 \%$ of men and $46,9 \%$ of the women. For $77,8 \%$ of the men the most frequent consumption is of $150-200 \mathrm{ml}$. at the same time, and the remaining $22,2 \%$ consume more that $250-300 \mathrm{ml} .3 .3 \%$ of the men consume more that 4 cups. Unlike the men, the women consuming $50-100 \mathrm{ml}$ of wine are with the larger share $-48,8 \%$, followed by the share of women, consuming $150-200 \mathrm{ml}-45,1 \%$. The indicators for the consumption of larger quantities $250-300 \mathrm{ml}$ and more are lower - every $13^{\text {th }}$ woman - consumer (Table 35$)$.

Table 35

\begin{tabular}{|l|l|l|l|l|l|l|}
\hline \multirow{2}{*}{$\begin{array}{l}\text { If you use it what quantity you drink at once } \\
\text { (vine) }\end{array}$} & \multicolumn{2}{|l|}{ Men } & Women & Total & \multicolumn{2}{l|}{} \\
\cline { 2 - 8 } & number & $\%$ & number & $\%$ & number & $\%$ \\
\hline $50-100 \mathrm{ml}$ & 0 & 0,0 & 40 & 48,8 & 40 & 44,0 \\
\hline $150-200 \mathrm{ml}$ & 7 & 77,8 & 37 & 45,1 & 44 & 48,4 \\
\hline $250-300 \mathrm{ml}$ & 1 & 11,1 & 4 & 4,9 & 5 & 5,5 \\
\hline more & 1 & 11,1 & 1 & 1,2 & 2 & 2,2 \\
\hline
\end{tabular}

Beer is consumed by $38.2 \%$ of men and $21.7 \%$ of women. One bottle of beer at once drank $52.4 \%$ of men, two bottles at a time $-28.6 \%$, three bottles at a time $-14.3 \%$, and more $-4.8 \%$ of them. Consumption within women reveals differences from men. All have indicated consumption of one bottle at a time (Table 36 ). 
Table 36

\begin{tabular}{|l|l|l|l|l|l|l|}
\hline \multirow{2}{*}{$\begin{array}{l}\text { If you use it what quantity you drink at once } \\
\text { (beer) }\end{array}$} & \multicolumn{2}{|l|}{ Men } & \multicolumn{2}{l|}{ Women } & \multicolumn{2}{l|}{ Total } \\
\cline { 2 - 8 } & number & $\%$ & number & $\%$ & number & $\%$ \\
\hline 1 & 11 & 52,4 & 38 & 100,0 & 49 & 83,1 \\
\hline 2 & 6 & 28,6 & 0 & 0,0 & 6 & 10,2 \\
\hline 3 & 3 & 14,3 & 0 & 0,0 & 3 & 5,1 \\
\hline more & 1 & 4,8 & 0 & 0,0 & 1 & 1,7 \\
\hline
\end{tabular}

The data showed that $98,3 \%$ do not feel the need to drink something alcoholic since the morning. In $1.3 \%$ this happens very rarely, and in $0.4 \%$ always (Table 37 ).

\section{Table 37}

\begin{tabular}{|l|l|l|l|l|l|l|}
\hline \multirow{2}{*}{$\begin{array}{l}\text { Did you need to drink anything alcoholic in the } \\
\text { morning? }\end{array}$} & \multicolumn{2}{|l|}{ Men } & \multicolumn{2}{l|}{ Women } & \multicolumn{2}{l|}{ Total } \\
\cline { 2 - 8 } & number & $\%$ & number & $\%$ & number & $\%$ \\
\hline Yes & 0 & 0,0 & 1 & 0,6 & 1 & 0,4 \\
\hline No & 52 & 94,5 & 174 & 99,4 & 226 & 98,3 \\
\hline Very rarely & 3 & 5,5 & 0 & 0,0 & 3 & 1,3 \\
\hline
\end{tabular}

The overdrink with or without occasion is usually in $2.6 \%$ of the persons, and very rarely - in $10.0 \%$. More common is for men compared to women (Table 38).

Table 38

\begin{tabular}{|l|l|l|l|l|l|l|}
\hline \multirow{2}{*}{$\begin{array}{l}\text { Normally, do you overdrink with or without } \\
\text { occasion? }\end{array}$} & \multicolumn{2}{|l|}{ Men } & \multicolumn{2}{l|}{ Women } & \multicolumn{2}{l|}{ Total } \\
\cline { 2 - 7 } & number & $\%$ & number & $\%$ & number & $\%$ \\
\hline Yes & 4 & 7,3 & 2 & 1,1 & 6 & 2,6 \\
\hline No & 38 & 69,1 & 163 & 93,1 & 201 & 87,4 \\
\hline Very rarely & 13 & 23,6 & 10 & 5,7 & 23 & 10,0 \\
\hline
\end{tabular}

Regarding the health status of the respondents, the survey results are negative and indicate a strong predominance of negative behavioral factors of life, such as:

1. Nutrition of the working people in the examined enterprise of the sewing industry in Bulgaria is not sufficiently healthy.

2. The locomotor activity of respondents is low.

3. The share of smokers is high, especially when more that half of the smokers are men.

4. The preferred form of alcohol taking for every second man and every third woman is a concentrate.

The conclusios made impose immediate compulsory measures in order to widen the health awareness of the employees aiming at improving their lifestyle and neurtalization of the behavioral risk factors triggering the chronic non-commnicalbe diseases.

\section{References:}

[1] Brown M, Sinacore DR, Host $\mathrm{HH}$. The relationship of strength to function in the older adult. Journal of Gerontology. 1995;50A:55-59.

[2] Markov, P., Markov, D., Vodenicharova, A., Baykova, D., The role of social factors in decision making about changes in lifestyle and diet, Ролята на социалните фактори при вземане на решения за промени в стила на живот и хранене. KONTAKT Journal, Sofia, TEMTO, 2015, pp.238-242.

[3] National Program for Prevention of the chronic non-communicable diseases 2014-2020 
[4] Staykova, J., Risk factors for the chronic non-communicable diseases, Kardzhali zone of CINDY Program Bulgaria, Public Health in the crysis situation, Faculty of Public Health, Medical University - Sofia, 2015, pp.126156, ISBN 978-619-7000-03-0.

[5] Titopoulou, M., Staykova, J., The role of the health and the safe and healthy working conditions in the changing world of labor, KONTAKTI Journal, Year XVI, issue 04 (104), 2016, pp. 50-53; ISSN 1311-7939

[6] Vodenicharov, C., Popova, S., Shipkovenska, E., Social Medicine, Sofia, 2013, p. 500

[7] WHO Global status report on noncommunicable diseases 2014 